\title{
Problems and Prospects of Plastic Money in Bangladesh
}

\author{
Farhana Rahman Sumi ${ }^{1}$, Ayesha Binte Safiullah ${ }^{2}$ \\ ${ }^{1}$ (Business Studies, University of Information Technology and Sciences, Bangladesh) \\ ${ }^{2}$ (Business Studies, University of Information Technology and Sciences, Bangladesh)
}

\begin{abstract}
Due to the technological revolution in financial sector, the transactions in banking system have undergone a tremendous change. Customers have showed their preference over the usage of the plastic money generally over a period of time. Plastic money is an alternative to the cash or the standard 'money'. Plastic money refers to the credit cards or the debit cards that is used to make purchases. Various other types of plastic cards provided by banks in Bangladesh are ATM cards, Smart cards. The current study presents an overview of the development of banking in the plastic cards usage trends since these have been introduced in Bangladeshi banking sector. The study also highlights the problems faced by the users of these cards as electronic payment tool. The Study is been carried out by taking a survey of 68 respondents by non probabilistic convenience sampling method from the city of Dhaka by using structured questionnaire and interview technique. The factors for adoption of plastic money in replacement of cash and paper money have been identified which shows the preference of the customers for plastic cards over the cash and paper money. Some future plans made by various banks and institutions for avoiding the frauds arisen due to the credit and debit cards are also been discussed in a way that it depicts the picture of its future growth and prospects in Bangladesh.
\end{abstract}

Keywords: Plastic Money, Plastic cards, ATM (Automated Teller Machine), Debit card, Credit card, Electronic Banking, Information Technology.

\section{Introduction}

In the modern world, banking sector of Bangladesh is growing very much rapidly than any other businesses. The entire bank industry is emphasizing on improvement with the help of technology. With the advancement of technology, several different products and services have been delivered to the customers and plastic money is the most important one. Now a days a modern client cannot think of banking without the facility of plastic cards. Today credit and debit cards have largely replaced cheques as alternatives to cash. Both are reasonably secured compared to cash and are widely accepted.

The availability of plastic cards with every account holder has changed the definition of banking in recent time. The evolution of plastic money industry was quite obvious as people are getting more dependent on technology and plastic money business is just the best outcome of technology in banking business. Because carrying wads of cash for a weekly or monthly shop is risky and not having enough when you get to the till is embarrassing. Those days are gone when we had to carry loads of cash and plan our shopping sprees. To keep their money secure is an age old problem. Plastic money is just the replacement of cash. It is such an electronic module where all the information about the client/card holder and the bank are stored and can be executed by putting it in the Automated Teller Machine. It's not only convenient but also very reliable and safe. In most of the developed countries, plastic money has replaced the paper currency on a large scale and is now being adopted in developing countries gradually.

Plastic Money business is definitely going big time in Bangladesh. More and more local and international financial institutions are exhibiting enthusiasm in this direction. It reflects prospects in Bangladesh market in accommodating numerous credit card competitors operating on the circuit, ensuring healthy and competitive card business deals.

\section{Scope and Objective of the Study}

This study was conducted by selecting 68 respondents randomly and was developed to find the following objectives:

- To assess the level of adoption and use of plastic money as payment system in Bangladesh.

- To analyze the factors for adoption of plastic money that replaces the paper or cash money.

- To find problems of using plastic money and some measures for avoiding frauds arouse due to plastic cards.

\section{Literature Review}

Money is always regarded as an important medium of exchange and payment tool. But over the years, money has changed its form from coins to paper cash and today it is available in formless form as electronic money or plastic card (Ramasamy et. al., 2006) [1]. Hence, the major change in banks which has been brought 
in by technology is through introducing products those are alternative to cash or paper money. Plastic cards are one of those types of innovations through which the customers can make use of banking services just by owning the card issued by bank and that too without restricting himself in the official banking hours. Plastic money' mainly represents debit and credit cards that allow cash to be drawn from an ATM booth or shopping to be done on credit. Both these modes eliminate the need to have actual cash at hand during purchase.

\subsection{Meaning of Plastic Money}

Plastic money is just the replacement of cash. It is such an electronic module where all the information about the client/card holder and the bank are stored and can be executed by putting it in the Automated Teller Machine and at the Point of Sales (P.O.S.) terminal. It's not only convenient but also very reliable and safe. In this type of card inside a magnetic strip all the necessary information about the customers are kept by reading, which the ATM machine can deliver the required money of the customer. The entire process is so secured and swift that it is really a big asset for the banks and that is why all the banks are trying to improve the service that being provided through plastic cards. Types of Plastic Cards: Credit card, Debit card, Payment/Prepaid/Electronic purse card, ATM cards, Store, Budget or option cards, charge cards, Gift cards etc.

\subsection{Types of Plastic Money}

Several kinds of cards have been issued in our country. These are-

Credit Cards: The term "credit card" generally refers to a plastic card issued to a cardholder, with a credit limit, that can be used to purchase goods and services on credit or obtain cash advances. It can be called as an equivalent of a loan sanctioned by the bank to its customers. Credit card facilitates and makes it possible to "Use First and Pay Later" the specified amount of credit as per the agreed terms of sanction. This card facilitates the cardholder to purchase goods and services from the merchant establishments and shops through the collaborating credit card companies like VISA, MasterCard, Maestro, and Cirrus. Unlike debit cards, credit cards also provide overdraft facility and customer can purchase over and above the amount available in his account and thus regarded as authentic payment tool (Mishra, 2007) [2]. Interest charges are levied on the unpaid balance after the payment is due. Clearing and settlement through credit card is a simple and reliable process in which bank plays a crucial role.

Debit Cards: A Debit Card provides for online electronic payment like Credit Card but from savings or current accounts of the cardholder for purchases. It is a magnetically encoded plastic card issued by banks which has replaced cash and cheques. It allows the customers to pay for goods and services without carrying cash with them. In some cases, debit card is multipurpose which can also be used as ATM for withdrawing cash and to check account balances. It is issued free of cost with the savings or current account (Mishra, 2007). This card is a deposit access product where cardholder uses his own money in his bank account through the debit card on the principle of "Pay First and Use Later". Debit card contains the symbol or hologram of collaborating company such as VISA, MasterCard, Maestro and Cirrus etc.

ATM Cards: ATM Card can be used to withdraw money, deposit money, balance enquires, deposit bills in the account. The cardholder must maintain a savings bank account or current account with the bank. On issuance of card, the cardholder is intimated a four digit secret Personal Identification Number (PIN). The cardholder is always required to maintain safely the PIN to prevent fraudulent activity. The system checks the account for adequate funds before permitting any transaction.

ATM Card-cum-Debit Card: ATM Card-cum-Debit Card can be used both as an ATM card and Debit card as a method of payment when purchasing goods and services in Bangladesh and Overseas. The cardholder is responsible for all transaction made by the use of the card. In Bangladesh most of the debit cards issued by banks are also ATM cards. For example, Dhaka Bank Limited, DBBL, SCB, HSBC, BRAC Bank and other banks operating in Bangladesh provides ATM Card-cum-Debit Card.

\subsection{Evolution of Plastic Money in Bangladesh}

A number of banks in Bangladesh are encouraging people to use plastic cards specially credit cards. The concept of credit card was used in 1950 with the launch of charge cards in USA by Diners Club and American Express. Credit card however became more popular with use of magnetic strip in 1970. Credit card in Bangladesh became popular with the introduction of foreign banks in the country though credit card was introduced in Bangladesh in 1997 by a local bank namely National Bank. There are thirteen banks and one financial institution issuing Credit Cards in Bangladesh. They are-Standard Chartered Bank, National Credit \& Commerce (NCC) Bank, Premier Bank, Prime Bank, Arab Bangladesh (AB) Bank, Dhaka Bank, Southeast Bank, National Bank, The City Bank, United Commercial Bank, Mercantile Bank, EXIM Bank, One Bank and Lanka Bangla. 
In addition to credit cards, debit cards, another example of plastic money, are now being introduced in Bangladesh. Money spent using these cards are deducted automatically from a bank account. Debit cards in particular are rapidly growing more popular. In fact debit cards look like credit or ATM cards, but work like cash or a personal cheque. Currently there are more than two lakhs credit card holders in Bangladesh. The growth of credit cards has had an enormous impact on the economy's changing buying habits by making it much easier for consumers to finance purchases and by lowering savings rates because consumers do not need to save money for larger purchases. Technology advances have facilitated the use of credit cards. Merchants are now connected to banks by modem, so purchases are approved rapidly online shopping on the internet is possible with credit card payment. Credit card companies are also experimenting with smart cards that would act like a small computer storing account and other information necessary for its use. An alternative to credit card is the debit card, which is used to deduct the price of goods and service directly from customer's bank balances.

\subsection{Present Scenario of Plastic Money Market in Bangladesh National Payment Switch (NPS)}

Bangladesh Bank has started implementing the National Payment Switch (NPS) since March, 2012. The NPS means the whole of the services that are associated in sending, receiving and processing orders of payment or transfers of money in domestic or foreign currencies, issuance and management of payment instruments, payment, clearing and settlement systems. The NPS basically acts as a mother switch and connects all the switches owned or shared by banks and non-banks in Bangladesh. Each child switch has a single interface with the NPS through which it sends inter-bank transactions originating from their alternate delivery channels, namely ATM, POS, KIOSKS, E-Commerce, internet banking, mobile banking, etc. The NPS supports transactions made through cards or account numbers, clear and settle these electronic transactions through the settlement accounts of all the scheduled banks maintained with the Bangladesh Bank. It has interfaces with all the major international payment schemes i.e. VISA, MasterCard.

\section{Availability of Different Brands}

VISA and Master Cards are famous international brands marketed in Bangladesh since long. Afterwards, the City Bank introduced American Express (Amex) Brand. AMEX (established in 1850), VISA (1958) and Master (1966) are basically US-origin brands. Recently, the Prime Bank Ltd has launched JCB Brand which is basically a Japanese Brand, namely Japan Credit Bureau, established in 1961 and they are offering 10 per cent cash back offer to shops at the super shop Agora. The DBBL has started acquiring Union Pay card at its ATM and POS terminals which is basically a Chinese Brand established in 2002. VISA is the market leader in Bangladesh and the DBBL is the largest debit card issuing bank.

\section{Stakeholders' Benefits}

Banks are now offering debit and credit cards. Debit card is for the account holders who can withdraw their own money from their accounts. It helps the account holders use their money without physically carrying it. On the other hand, credit cards are issued in favour of the financially eligible users who can use this card for purchasing any permissible items, booking hotels etc.

No charges, except annual service charges, are deducted for any debit card transaction at present. But in case of withdrawal of money of any bank through debit card from other banks' ATM booths, the card issuing bank has to pay some charges. Lots of banks have network-sharing agreement with the DBBL as it has the largest network with 2,600 units of ATMs installed by it throughout the country. The DBBL earns a huge income from sharing their network with other enlisted banks. For example, one of the leading private commercial banks had an agreement with the DBBL until September, 2014 for sharing their 1,100 ATM booths at the cost of Tk. 3,000 per booth per month. Till March, 2014, under Q-Cash ATM network and Omnibus ATM network, inter-bank charges for each transaction were Tk.11.50 and Tk.17.25 (including VAT) respectively. In case of using other banks' network without any specific agreement by VISA/Master logobearing debit card, the cardholder has to pay up to Tk. 150 per transaction.

Now, after becoming the member of the National Payment Switch (PNS), each bank will have to pay transaction-wise charges to other banks for using their network. As per the Bangladesh Bank's instruction (PSD Circular No. 01 dated 18.03.2014) no bank shall impose any charge on individual transaction made from ATM booths of the card-issuing banks. However, if the transaction is made from any ATM booth other than cardissuing bank, then Tk. 20 will be charged for each transaction out of which the cardholder will pay Tk. 10 and card- issuing bank will subsidise Tk. 10 and in case of printing any balance inquiry or mini statement from other banks ATMs, cardholder will have to pay Tk. 5.00.

In case of credit card transaction, except electronics and gold items, no additional charge is deducted from the cardholder. There is an agreement between banks and merchants over a specified commission rate. For example, in case of purchasing goods from super shops, if the credit card and POS of that shop are of the same 
bank, then 1.6 per cent to 2.0 per cent commission is deducted from the merchants' bill by the bank. Being the brand issuer, VISA \& Master Card will get around 0.005 per cent from the gain and remaining amount will be the ultimate gain of the card-issuing bank. If the card-issuing bank and POS bank are different, then commission will be divided among the brand, issuing bank and POS bank. Maximum charge is deducted for electronics and gold items and fully deducted from the cardholders' account.

\subsection{Advantage of Plastic Money in Bangladesh}

From the point of view of a cardholder, the main benefit is convenience. The cardholder does not require to carry cash money. Another benefit is payment on a later date. Generally, a credit cardholder gets maximum 45 days' interest-free time span to repay the amount. If anybody fails to repay within 45 days, then interest is charged from the date of purchase at a pre-agreed rate.

In most cases, card-issuing banks offer special benefits like cash back offer, discount at different scales with products of different companies, bonus point system which can be converted into Taka or equivalent benefit, corporate package with different bodies specially with medical service providers, airlines, amusement/theme parks etc to entertain their cardholders throughout the year.

A credit card transaction is more secure than other forms of payment like accepting cheques, because a cheque may be refused for insufficient fund but in case of credit card transaction, the issuing bank is committed to pay the merchant the moment the transaction is authorised, regardless of whether the consumer defaults on the credit card payment.

In most cases, cards are even more secure than cash, because there is no possibility of theft by the cashiers of the merchants. Credit cards reduce the administrative expense of processing cheque/cash and transporting them to the bank. Due to credit cards, sales of the merchants increase because in some cases people buy something using cards which they might not buy in cash.

\subsection{Disadvantage of Plastic Money in Bangladesh}

Individual ATM booths are situated at different types of location from crowded commercial areas to remote, sleepy areas. To maintain security of these booths is a big challenge. Very often it is reported that miscreants loot money after killing the security guard. Large-scale ATM corner having several machines may be maintained with adequate manpower that will ensure safety and reduce operational cost.

In most cases, credit cards are issued as an unsecured loan. Therefore, it has become a common phenomenon that a cardholder does not show willingness to pay bank's dues in time. A large amount of money of credit cards lying outstanding with all the banks has turned into classified and most of the customers have become traceless. It is due to lack of monitoring and lapse of due diligence while issuing cards. In some instances, bank's card divisions employ third-party concerns or temporary sales representatives for card marketing. These people are paid a nominal fixed salary and they can earn extra money by selling cards or fulfilling fixed targets. As such they are always concerned about target fulfilling and issuance of more cards. In some cases, banks appoint third-party verifier namely 'Contact Point Verifier' (CPV) who verifies the addresses of the applicants. Reliability of these CPVs is also in question because in case of any default, no action can be taken against him.

As per NPS transaction guideline, if a cardholder withdraws money from other banks' ATM, then Tk. 10 is charged from the card and the issuing bank will have to compensate another Tk.10. This amount is actually not lucrative for the marginal users. So, there should have a ceiling on withdrawal of amount where no charges will be deducted from the cardholders' account.

One of the major problems of using credit card is that it is freely transferable to others. It is assumed that users will verify the signature and photo embossed in the card with card-presenter. But in maximum cases, they never see the signature and seldom match the photo. Therefore, any other person can purchase with others' credit card which is stolen or willingly transferred unless it is reported to the issuing banks in due course of time. In such cases, banks are not liable for using stolen cards. Banks can make it mandatory that signature in the bill and in the card should match while charging cards and it is merchandisers' responsibility. Otherwise, banks shall not pay the bill. Thus fraudulent use of cards may be reduced.

Bank's card divisions issue cards to the applicants and provide limit. A secret PIN is provided to the cardholder later on to activate the card. It is alleged that some bank officials issue fake credit cards. The same officials provide limit and they themselves generate PIN numbers to activate the cards. Thus, they snatch away a huge amount against credit cards in cases where cardholders do not exist in reality.

\section{Methodology}

The present study is mainly based on primary and secondary data related to Plastic money. Secondary data and information have gathered from Books, Journals, research paper etc. Primary data and information also have collected through using observation and interview method. 


\subsection{Demographic Analysis}

\section{Analysis and Findings}

Some important demographic information has been considered, among those- age, occupation and genders are considered. Respondents' ages lie within 15 to 55 years. The demographic characteristics also show a gender division of the respondents, majority of the respondents are males, i.e. 54.4 percent and 45.60 percent of the respondents are female. $33.82 \%$ of the employees earned between Tk. $35000-$ Tk. 55000. There is occupation wise variation among respondents and 44.12 percent of the respondents are professionals (i.e. Teachers, doctors, engineers). Table 1 shows the demographic information of the respondents.

Table 1: Personal profile of the respondents $(\mathrm{N}=68)$

\begin{tabular}{|l|l|l|l|l|}
\hline Profile & Frequency & Percentage & Valid Percentage & Cumulative Percentage \\
\hline Gender & 37 & 54.40 & 54.40 & 54.40 \\
\hline Male & 31 & 45.60 & 45.60 & 100.0 \\
\hline Female & \multicolumn{5}{l}{} \\
\hline Age & 7 & 10.29 & 10.29 & 10.29 \\
\hline 15-24 Years & 33 & 48.53 & 48.53 & 58.82 \\
\hline 25-34 Years & 12 & 17.65 & 17.65 & 76.47 \\
\hline 35-44 Years & 15 & 22.06 & 22.06 & 98.53 \\
\hline 45-54 & 1.47 & 1.47 & 100.0 \\
\hline 55 and above & 1 & & 10.29 \\
\hline Occupation & 7 & 10.29 & 10.29 & 54.41 \\
\hline Student & 44.12 & 44.12 & 70.59 \\
\hline Professional & 30 & 16.17 & 16.17 & 100.0 \\
\hline Administrative & 11 & 29.41 & 29.41 & 10.29 \\
\hline Own Business & 20 & 10.29 & 10.29 & 44.11 \\
\hline Salary in BDT & \multicolumn{5}{|l|}{} & 63.23 \\
\hline Below 20000 & 7 & 33.82 & 33.82 & 82.35 \\
\hline 20000-35000 & 23 & 19.12 & 19.12 & 100.0 \\
\hline 35000-55000 & 13 & 19.12 & 19.12 & 17.65 \\
\hline 55000-100000 & 13 & 17.65 &
\end{tabular}

From this study, it is found that respondents those who are working in different organizations as professionals or working in administrative activity, they are highly using debit cards of different banks. The banks that they select depend on their organization. Usually they have salary accounts of those banks and thus have debit cards. It is also found that female counterparts tend to use credit cards less than their male counterparts in Bangladesh (Table 3). Mostly they use supplementary credit cards.

Table 2: Debit and Credit card user (Gender wise)

\begin{tabular}{|l|l|l|}
\hline Gender & Debit Cards User & Credit Cards User \\
\hline Male & $72.97 \%$ & $48.65 \%$ \\
\hline Female & $77.42 \%$ & $41.94 \%$ \\
\hline
\end{tabular}

Figure 1: Gender wise plastic money users

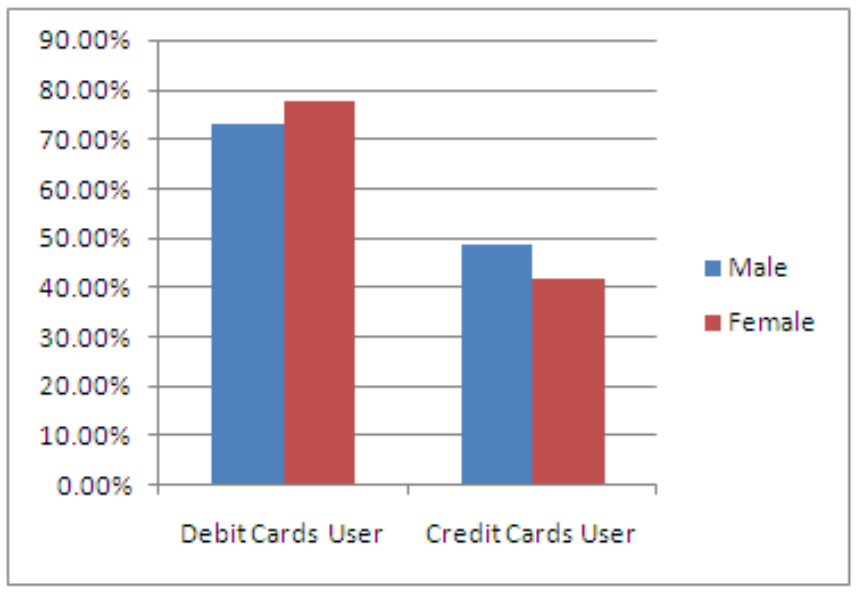

Source: Authors own survey 
Table 3: Debit and Credit card user (Occupation wise)

\begin{tabular}{|l|l|l|}
\hline Gender & Debit Cards User & Credit Cards User \\
\hline Student & $0 \%$ & $0 \%$ \\
\hline Professionals & $100 \%$ & $56.66 \%$ \\
\hline Administration & $100 \%$ & $81.81 \%$ \\
\hline Own Business & $50 \%$ & $35 \%$ \\
\hline
\end{tabular}

Figure 2: Occupation wise plastic money users

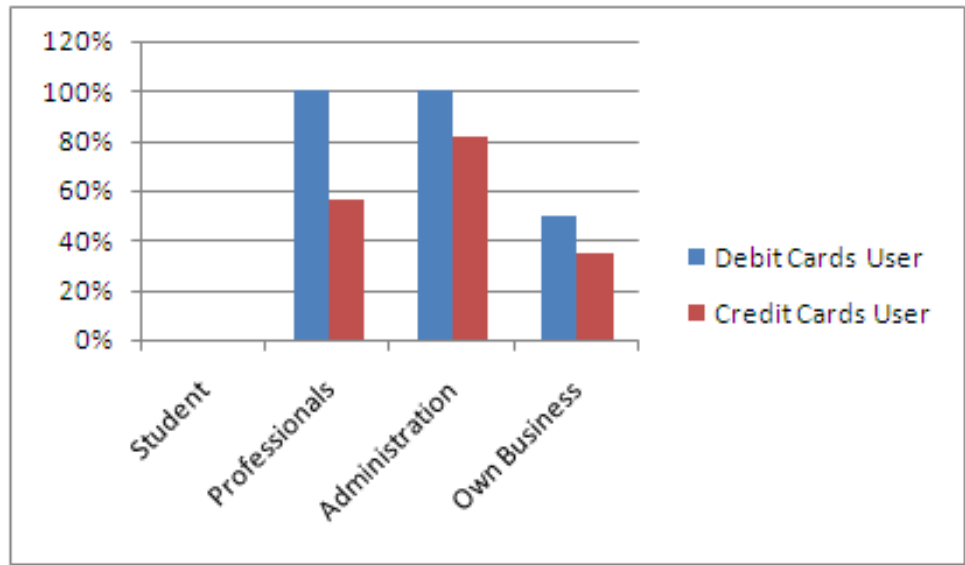

Source: Authors' own survey

Maximum users of debit cards are working as professionals and administrative employees. Among the respondents, those who are students do not use debit or credit cards.

Table 4: Users of different banks (According to the respondents)

\begin{tabular}{|l|l|l|l|}
\hline Banks & Percentage of Users & Debit Cards User & Credit Cards User \\
\hline Dutch Bangla Bank Ltd. & $14.70 \%$ & $100 \%$ & $70 \%$ \\
\hline Eastern Bank Ltd. & $10.29 \%$ & $57.14 \%$ & $28.57 \%$ \\
\hline Prime Bank & $20.59 \%$ & $64.29 \%$ & $57.14 \%$ \\
\hline City Bank & $16.18 \%$ & $18.18 \%$ & $18.19 \%$ \\
\hline Brac Bank & $30.88 \%$ & $100 \%$ & $61.90 \%$ \\
\hline HSBC Bank & $7.35 \%$ & $100 \%$ & $0 \%$ \\
\hline
\end{tabular}

Figure 3: Users of different banks

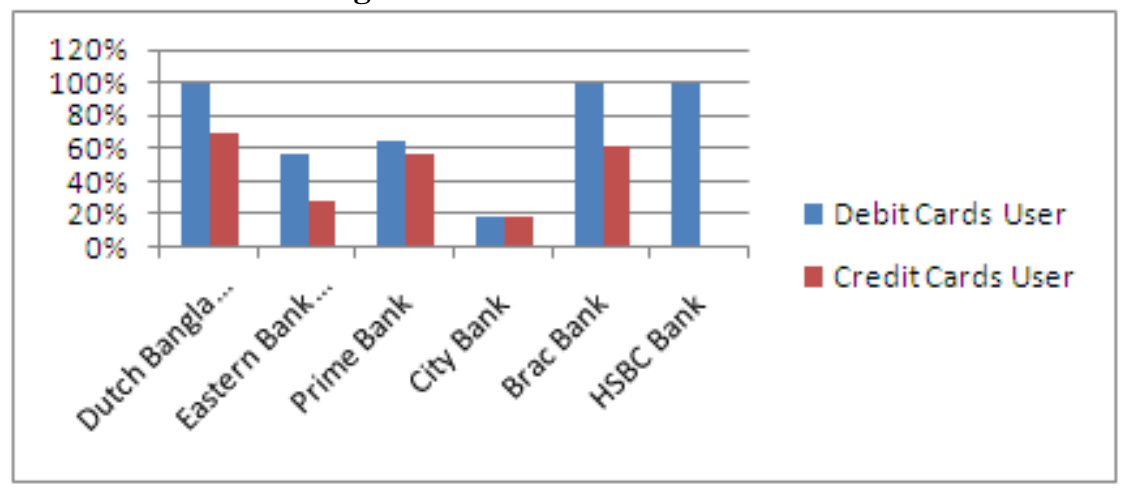

Source: Authors' own survey

\subsection{Purpose, Duration of Using Plastic money}

Customers use plastic money either for taka withdrawal or for purchase of goods and services or for both. This study shows that 80 percent respondents use plastic money for taka withdrawal, while 12 percent use it for purchasing goods and services. Only 8 percent respondents use it for both purposes. Duration of plastic money use is different for different customers.

The study also shows that 25 percent of the respondents are using plastic money for 1-3 year, 56 percent of the respondents are using it for 3-6 years and others are using for 6- more than 6 years. It is also noteworthy that the usage pattern of customers is different. Some users use it just one time per month while some others use it 4 or more times. This study indicates that 40 percent users use only 1-2 times per month for 
taka withdrawal or purchase of goods and services or for both, while 30 percent users use plastic money more than four times for the same purpose.

Table 5: Purpose of using plastic money

\begin{tabular}{|l|l|}
\hline Use of Plastic Money & Percentage of use \\
\hline Taka Withdrawal & $80 \%$ \\
\hline Purchase of Goods \& Services & $12 \%$ \\
\hline Use for Both Purpose & $8 \%$ \\
\hline
\end{tabular}

Table 6: Duration of using plastic money

\begin{tabular}{|l|l|}
\hline Duration of use & Users' percentage \\
\hline 1-3 years & $25 \%$ \\
\hline 3-6 years & $56 \%$ \\
\hline 6-more than 6 years & $19 \%$ \\
\hline
\end{tabular}

\subsection{Problems faced by respondents while using plastic money}

Satisfaction or dissatisfaction largely depends upon the problem that customers face when they use any product or consume any service. This is also applicable for plastic money. This study shows that 30 percent users have faced problem during their use of plastic money.

\section{Nature of Problem}

Problem is different for different respondents. Plastic money users faced the problem of unavailability of taka and receipt in the case of withdrawing taka from the ATM booths. However, it is interesting to mention that only 16 percent respondents got fake note during their transaction. 15 percent respondents did not get small value denominated notes while they wanted to withdraw taka from the booth. "Receipt was available but not taka" 69 percents did agree with this point. It has also happened that a single customer has faced different problems.

\section{Problem of Banks}

As customers have different types of problems, it is rationale to know in which bank's booth they faced that. The researchers have defined the bank whose customers have face problem for plastic money as 'Problem Bank'. It has been found that 54 percent customers of DBBL faced most problems, whereas HSBC banks's customers faced lesser problems during their plastic money use. It is noteworthy that some customers have faced problems in many banks.

\section{Satisfaction Factor}

Studies show that users' satisfaction is an essential determinant of success of the technology based delivery channels. Different factors affect users' satisfaction level differently. People use plastic money mostly to withdraw taka. So it is important to have sufficient amount of taka in the booth. This study shows the average position of the taka availability in the booth. In this case the customers are satisfied but not highly satisfied.

\section{Different value denominated notes}

Satisfaction among the plastic money users depends on many factors. Availability of different value denominated notes is one of the factors. According to the calculated mean value, customers are satisfied though 22 respondents are neutral. Therefore, some banks are lagging behind in this case.

\section{Network service}

Network service is the first and foremost condition to make plastic money users satisfied because without network transaction is not possible. This study shows that card users are somewhat satisfied regarding the network service. The percentage is only $62.34 \%$, which is very close to neutral value. It indicates a large member of respondents have faced problem in this connection.

\section{Recommendations and Conclusion}

Banking sector is the most competitive sector in the present business world. Thousands of customers are served by banks. Ultimate goal of the bank is to maximize the wealth of the owners. To achieve this goal, attention must be given to service quality. When plastic money users are satisfied, they will be attached to the bank for a long time. It will be strength for a specific bank to compete with other banks. It will help the growth of the plastic money users' confidence on the bank and users will be tempted. If banks want to sustain positively, there is no alternative but to satisfy the customers, especially the plastic money users, because they use it against their valuable deposited money in the bank. Bank must improve its strategies to fill up the demand 
of Plastic money users because if the users switch to another bank, the particular bank will lose some cash flow that will negatively affect the goal of the bank. It is hoped that all the banks will come forward to think about this matter. For better plastic money service, the following strategies are recommended:

- Banks should improve the network service quality so that customers are not refused when they go to ATM booth.

- As customers want to be updated about their account balance, plastic money transaction should provide receipt always.

- Banks should increase their own booth. As own booth is cost free, customers always prefer to use it.

- Some customers have recommended that banks should reduce the transaction cost of Plastic money. They have to pay this cost when use other bank's ATM booth.

- Banks can make agreement with shopping centers so that customers can easily use Plastic money at those places. This arrangement will help reduce the hazards of purchasing.

- Sometimes customers do not get Taka from booth though that is automatically reduced from their account. This is a main factor for users 'dissatisfaction. Banks can take initiatives to solve this problem promptly.

- As users need different value denominated notes, banks should keep most of the value denominated notes in the booth (Taka 100 multiples).

\section{References}

[1]. Ramasamy S R, Guru K B, Nair M and Vaithilingam S, Development of EMoney EMoney in Malaysia, National Statistics Conference, 2006, Putrajaya International Convention Centre, Putrajaya, Malaysia.

[2]. Mishra Gaurie, Indians Get Elastic with Plastic Money, The Economics Times, Retrieved April 02, 2008 from http:// e c o n o m i c times.indiatimes. co m / articleshowl2382580.cms

[3]. Sharma,Anupama, Plastic card frauds and the countermeasures: Towards a safer payment mechanism, International Journal of Research in Commerce, IT \&Management, Vol. 2, No. 4, 2012.

[4]. Plastic Money-Pros and Cons, Retrieved on November 21, 2014 from http://www.wisdomtimes.com/blog/plastic-money-pros-andcons/

[5]. http://mymoneyskills.com/mms/ap/using your cards wisely/benefitsplastic.shtml

[6]. Soyeb, S, Project Paper on Plastic Money Market of Bangladesh: Sales Management of Brac Bank ATM Card, Retrieved on November 21, 2014 from http://www.scribd.com/doc/248408944/Project-Paper-on-Plastic-Money-Market-of-BangladeshSales-Management-of-Brac-Bank-ATM-Card

[7]. Palash, Hassan B, Plastic Money: Bangladesh Perspective, Financial Express, Vol 21, No. 338, 2014. Retrieved November 28, 2014 from http://www.thefinancialexpress-bd.com/2014/10/27/63112 